\title{
Bifunctional organocatalysts for the asymmetric synthesis of axially chiral benzamides
}

\author{
Ryota Miyaji, Yuuki Wada, Akira Matsumoto, Keisuke Asano* and Seijiro Matsubara*
}

\section{Full Research Paper}

\section{Address:}

Department of Material Chemistry, Graduate School of Engineering, Kyoto University, Kyotodaigaku-Katsura, Nishikyo, Kyoto 615-8510, Japan

Email:

Keisuke Asano* - asano.keisuke.5w@kyoto-u.ac.jp;

Seijiro Matsubara* - matsubara.seijiro.2e@kyoto-u.ac.jp

* Corresponding author

Keywords:

axial chirality; benzamide; bifunctional organocatalyst; molecular

conformation; multipoint recognition
Beilstein J. Org. Chem. 2017, 13, 1518-1523.

doi:10.3762/bjoc. 13.151

Received: 21 April 2017

Accepted: 18 July 2017

Published: 02 August 2017

Associate Editor: M. Rueping

(C) 2017 Miyaji et al.; licensee Beilstein-Institut.

License and terms: see end of document.

\begin{abstract}
Bifunctional organocatalysts bearing amino and urea functional groups in a chiral molecular skeleton were applied to the enantioselective synthesis of axially chiral benzamides via aromatic electrophilic bromination. The results demonstrate the versatility of bifunctional organocatalysts for the enantioselective construction of axially chiral compounds. Moderate to good enantioselectivities were afforded with a range of benzamide substrates. Mechanistic investigations were also carried out.
\end{abstract}

\section{Introduction}

Bifunctional organocatalysts have significantly contributed to the field of asymmetric synthesis [1-6]. In these catalysts, (thio)urea and tertiary amino functional groups cooperatively activate a nucleophile and an electrophile simultaneously, in a suitable spatial configuration. Thus, they enable various stereoselective addition reactions to occur. Organocatalysts have also been employed in several asymmetric cyclization reactions via intramolecular hetero-Michael addition [7-16]. In these reactions, multipoint recognition by the catalysts favors the specific conformations of the substrates in the transition state. Several successful results and a recent trend in organocatalytic atroposelective reactions, including enantioselective formation of chiral axes [17-24], dynamic kinetic resolution [25-41], kinetic resolution [42-47], desymmetrization [48-54], de novo annulation [55-61], and point-to-axial chirality transfer [58,59] (for reviews, see references $[31,62,63])$, motivated us to expand on the utility of this class of small-molecule catalysts. We have recently demonstrated that bifunctional organocatalysts can also be applied to the asymmetric synthesis of axially chiral compounds (biaryls bearing isoquinoline $N$-oxides or quinolines and phenolic moieties) by translating a specific conformation, recognized by bifunctional organocatalysts, into axial chirality $[36,37]$. Thus, we assumed that this method could be further applied to the enantioselective synthesis of a range of axially 
chiral compounds. In this study, we present the enantioselective synthesis of 3-hydroxybenzamides via aromatic electrophilic bromination $[28,29]$. The 3-hydroxybenzamide substrates comprise both amide and phenolic moieties. These can interact with a hydrogen-bond donor and a hydrogen-bond acceptor, respectively. Such interactions are expected to recognize a specific conformation of the substrate molecule to realize the enantioselective construction of axially chiral benzamides [36,37].

\section{Results and Discussion}

We initiated our investigations using 3-hydroxy- $N, N$-diisopropylbenzamide (1a) and $N$-bromoacetamide (NBA, 4a) as a brominating reagent, with $10 \mathrm{~mol} \%$ quinidine-derived bifunctional catalyst $\mathbf{3 a}$, in toluene, at $-40{ }^{\circ} \mathrm{C}$. As expected, the tribrominated product $\mathbf{2 a}$ was formed enantioselectively (Table 1, entry 1). Although a lower temperature did not improve the enantioselectivity (Table 1 , entry 2 ), lowering the concentration of the reaction mixture was effective (Table 1, entry 3 ). The screening of solvents identified ethyl acetate as the most suitable solvent (Table 1, entries 4-7). Other brominating reagents (Figure 1) were also investigated; however, NBA (4a) still afforded the best enantioselective results (Table 1, entries 8-10). In addition, other bifunctional organocatalysts derived from easily available cinchona alkaloids exhibited similarly good enantioselectivities; $\mathbf{3 c}$ and $\mathbf{3 d}$ afforded the opposite enantiomer of the product (Table 1, entries 11-13, results of further catalyst screening are described in the Supporting Information File 1).

Table 1: Optimization of conditions. ${ }^{\text {a }}$<smiles>CC(C)N(C(=O)c1cccc(O)c1)C(C)C</smiles>

$1 \mathbf{a}$

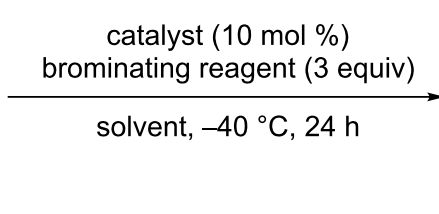

solvent, $-40^{\circ} \mathrm{C}, 24 \mathrm{~h}$<smiles>CC(C)N(C(=O)c1c(O)cc(Br)cc1Br)C(C)C</smiles>

$2 a$<smiles>C=CC1C2CCN1[C](C(NC(=O)NBr)c1ccnc3ccc(OC)cc13)[C@H]2C</smiles>

$3 a$

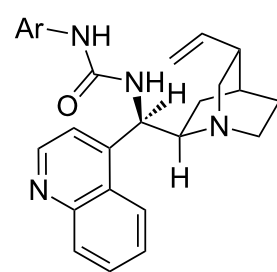

$3 b$<smiles>C=CC1CN2CCC1C2[C@H](NC(=O)NN)c1ccnc2ccc(OC)cc12</smiles>

$3 c$

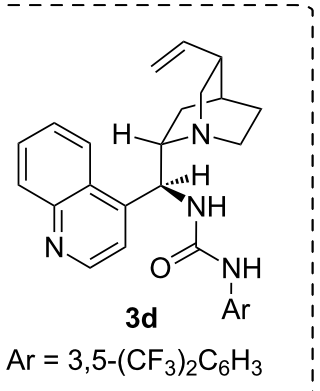

\begin{tabular}{|c|c|c|c|c|c|}
\hline Entry & Catalyst & Brominating reagent & Solvent & Yield $(\%)^{b}$ & ee $(\%)$ \\
\hline $1^{c}$ & $3 a$ & $\operatorname{NBA}(\mathbf{4 a})$ & toluene & 88 & 78 \\
\hline $2^{\mathrm{c}, \mathrm{d}}$ & $3 a$ & $\operatorname{NBA}(4 a)$ & toluene & 48 & 78 \\
\hline 3 & $3 a$ & $\operatorname{NBA}(\mathbf{4 a})$ & toluene & 58 & 84 \\
\hline 4 & $3 a$ & $\operatorname{NBA}(4 a)$ & $\mathrm{CHCl}_{3}$ & 73 & 84 \\
\hline 5 & $3 a$ & $\operatorname{NBA}(\mathbf{4 a})$ & $\mathrm{Et}_{2} \mathrm{O}$ & 66 & 42 \\
\hline 6 & $3 a$ & $\operatorname{NBA}(\mathbf{4 a})$ & THF & 69 & 82 \\
\hline 7 & $3 a$ & $\operatorname{NBA}(\mathbf{4 a})$ & EtOAc & 84 & 87 \\
\hline $8^{e}$ & $3 a$ & $\mathrm{DBH}(\mathbf{4 b})$ & EtOAc & 99 & 77 \\
\hline 9 & $3 a$ & NBS (4c) & EtOAc & 99 & 51 \\
\hline 10 & $3 a$ & $\operatorname{NBP}(\mathbf{4 d})$ & EtOAc & 99 & 72 \\
\hline 11 & $3 b$ & $\operatorname{NBA}(\mathbf{4 a})$ & EtOAc & 56 & 84 \\
\hline 12 & $3 c$ & $\operatorname{NBA}(\mathbf{4 a})$ & EtOAc & 89 & -81 \\
\hline 13 & $3 d$ & $\operatorname{NBA}(\mathbf{4 a})$ & EtOAc & 76 & -80 \\
\hline
\end{tabular}

${ }^{a}$ Reactions were run using $1 \mathrm{a}(0.1 \mathrm{mmol})$, the catalyst $(0.01 \mathrm{mmol})$, and the brominating reagent $(0.3 \mathrm{mmol})$ in the solvent $(10 \mathrm{~mL}){ }^{\mathrm{b}} \mathrm{lsolated}$ yields ${ }^{\mathrm{c}}$ Reactions were run in $0.5 \mathrm{~mL}$ of toluene. ${ }^{\mathrm{d}}$ Reaction was run at $-45^{\circ} \mathrm{C}$. ${ }^{\mathrm{e}} 1.5$ equiv of $4 \mathrm{~b}$ was used for the reaction. 
<smiles>CC(=O)NBr</smiles>

NBA (4a)<smiles>CC1(C)C(=O)N(Br)C(=O)N1Br</smiles>

DBH (4b)<smiles>O=C1CCC(=O)N1Br</smiles>

NBS (4c)<smiles>O=C1c2ccccc2C(=O)N1Br</smiles>

NBP (4d)
Figure 1: Brominating reagents.

We then investigated substrates bearing other substituents on the amino group (Scheme 1). Dimethyl- and diisobutylamide groups resulted in much lower enantioselectivities (2b and $\mathbf{2 c}$ ). Substrates bearing cyclohexyl groups or a piperidinyl moiety provided the corresponding products in high yields; however, the enantioselectivities were not as high as that of $\mathbf{2 a}$. The absolute configuration of $\mathbf{2 d}$ was determined by X-ray analysis (see the Supporting Information File 1 for details), and the configurations of all other examples were assigned analogously.

Once the optimal conditions for the transformation were established, we next proceeded to explore the substrate scope (Scheme 2). The substrate bearing a phenyl group yielded the product with the highest enantioselectivity (Scheme 2, 2f). However, a decrease in enantioselectivity was observed when the phenyl group was replaced by substituted phenyl groups (Scheme 2, 2g and $\mathbf{2 h}$ ). The substrate bearing a naphthyl group afforded the corresponding product in moderate enantioselectivity (Scheme 2, 2i). In addition, a benzamide with a cyclopropyl group also provided the product in good enantioselectivity (Scheme 2, 2j). Furthermore, when the reaction was carried out<smiles>[R]c1cc(O)cc(C(=O)N(C(C)C)C(C)C)c1</smiles><smiles>[R]c1c(Br)c(O)c(Br)c(C(=O)N(C(C)C)C(C)C)c1Br</smiles>

1<smiles>CC(C)N(C(=O)c1c(O)cc(Br)cc1Br)C(C)C</smiles>

2a

$84 \%$

$87 \%$ ee

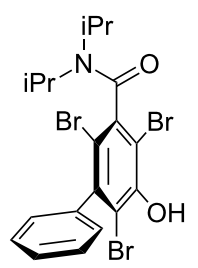

$\mathbf{2 f}$
$86 \%$

$90 \%$ ee

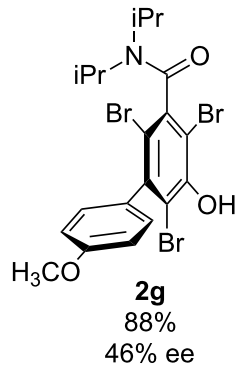

2

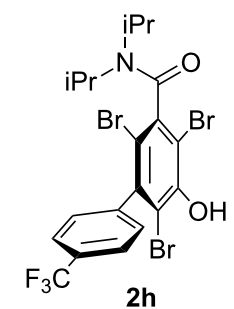

$\mathbf{2 h}$
$99 \%$

$24 \%$ ee
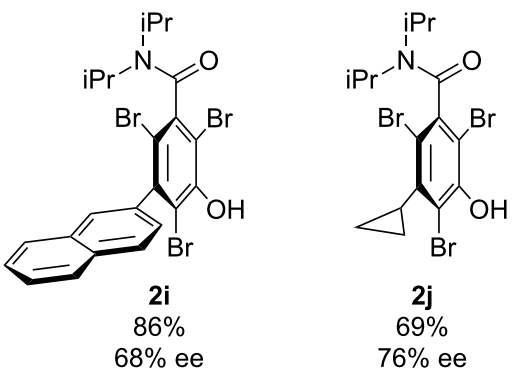

2j

$76 \%$ ee

Scheme 2: Substrate scope. Reactions were run using 1 (0.1 mmol), 3a $(0.01 \mathrm{mmol})$, and $4 \mathbf{a}(0.3 \mathrm{mmol})$ in EtOAc $(10 \mathrm{~mL})$. Yields represent material isolated after silica gel column chromatography.<smiles>[R]N([R])C(=O)c1cccc(O)c1</smiles>

1<smiles>CC(C)N(C(=O)c1c(O)cc(Br)cc1Br)C(C)C</smiles>

$2 a$

$84 \%$

$87 \%$ ee

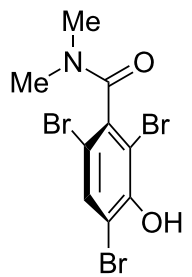

$2 \mathbf{b}$

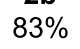

$6 \%$ ee

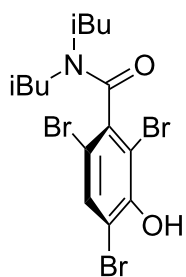

2c

$80 \%$

$8 \%$ ee

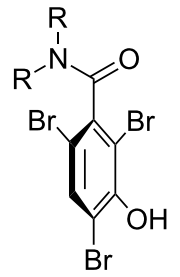

2
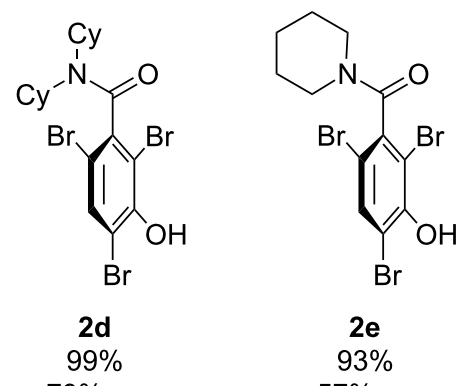

$79 \%$ ee
2 e

$93 \%$

$57 \%$ ee

Scheme 1: Optimization of the substituents of the amide group. Reactions were run using $1(0.1 \mathrm{mmol}), \mathbf{3 a}(0.01 \mathrm{mmol})$, and $\mathbf{4 a}(0.3 \mathrm{mmol})$ in EtOAc $(10 \mathrm{~mL})$. Yields represent material isolated after silica gel column chromatography. 
using $1 \mathbf{k}$ and $1 \mathbf{l}$ with 2 equiv of NBA (4a), dibromination proceeded in high yields and moderate enantioselectivities (Scheme 3); both $\mathbf{1 k}$ and $\mathbf{1 l}$ comprise a substituent ortho to the hydroxy group. These brominated axially chiral benzamides can further be derivatized for the synthesis of functional molecules [64].

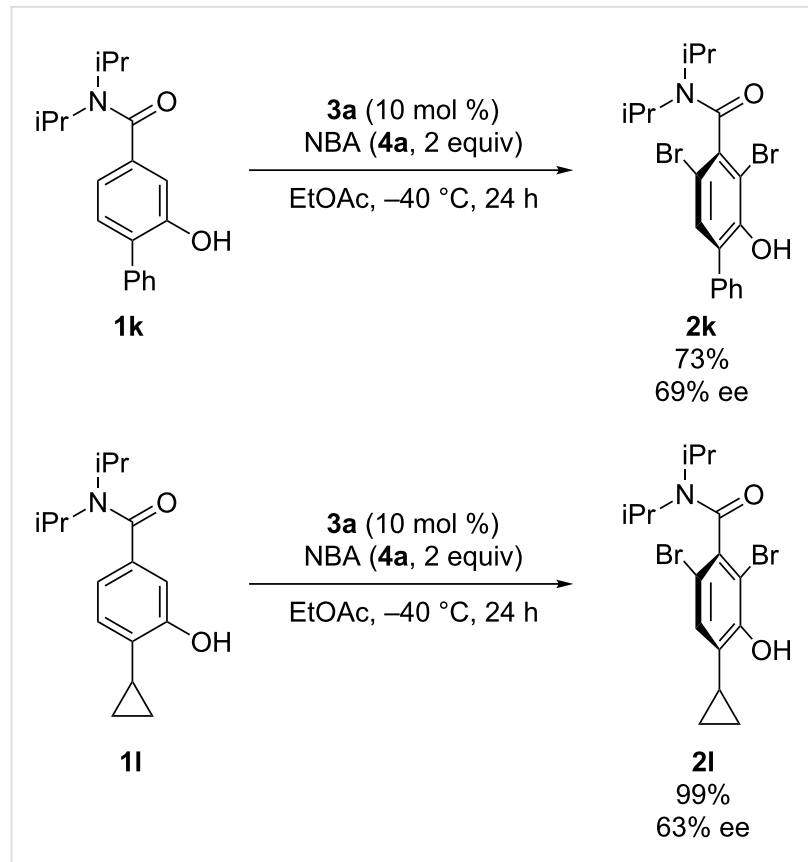

Scheme 3: Reactions of substrates with substituted phenols.

To gain insight into the reaction mechanism, the reactions were performed using substrates $\mathbf{1} \mathbf{m}$ and $\mathbf{1 n}$, previously monobrominated at the ortho-positions of the rotational axis. Much lower enantioselectivities than that afforded by $\mathbf{1 a}$ were observed in both reactions (Scheme 4). In addition, the reaction was also carried out with 1 equiv of NBA (4a). The sole product afforded was $1 \mathbf{m}$ and most of the starting material was recovered (see Supporting Information File 1 for details). These results imply that the first bromination, occurring at the ortho-position of the axis (probably at the 2-position), is the enantiodetermining step of the reaction. Moreover, once one of the ortho-positions is brominated, racemization through bond rotation is negligible during further brominations [65]. Indeed, the rotational barrier of substrate 1a, calculated at the B3YLP/6-31G(d) level of theory, is only $7.6 \mathrm{kcal} / \mathrm{mol}$; on the other hand, that of the monobrominated intermediate $\mathbf{1 m}$ is $19.0 \mathrm{kcal} / \mathrm{mol}$ (Scheme 5). However, this latter value is not high enough to inhibit bond rotation at room temperature. This explains why the reactions must be carried out at such a low temperature $\left(-40^{\circ} \mathrm{C}\right)$ to afford high enantioselectivities. Compound 1o, with both ortho-positions brominated, has a rotational barrier that is high enough to enable the isolation of the optically active form, even at room

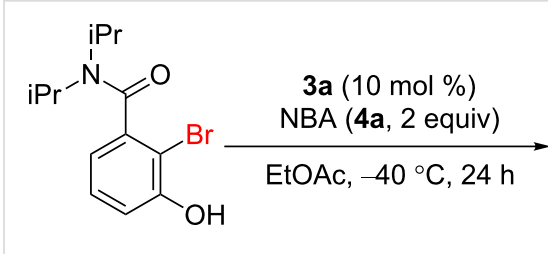

$1 \mathrm{~m}$

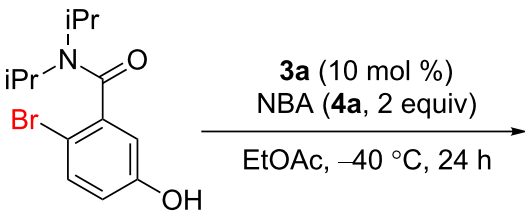

1n<smiles>CC(C)N(C(=O)c1c(Br)cc(Br)c(O)c1Br)C(C)C</smiles>

2a

$61 \%$

$8 \%$ ee<smiles>CC(C)N(C(=O)c1c(Br)cc(Br)c(O)c1Br)C(C)C</smiles>

2a

$54 \%$

$7 \%$ ee
Scheme 4: Reactions of monobrominated substrates.<smiles>CC(C)N(C(=O)c1cccc(O)c1)C(C)C</smiles>

$1 \mathrm{a}$

$7.6 \mathrm{kcal} / \mathrm{mol}$<smiles>CN(C)C(=O)c1cccc(O)c1Br</smiles>

$1 \mathrm{p}$<smiles>CC(C)N(C(=O)c1cccc(O)c1Br)C(C)C</smiles>

$1 \mathrm{~m}$ $19.0 \mathrm{kcal} / \mathrm{mol}$<smiles>CC(C)CN(CC(C)C)C(=O)c1cccc(O)c1Br</smiles>

19<smiles>CC(C)N(C(=O)c1c(Br)ccc(O)c1Br)C(C)C</smiles>

10<smiles>CN(C)C(=O)c1c(Br)cc(Br)c(O)c1Br</smiles>

2b

$14.2 \mathrm{kcal} / \mathrm{mol}$

$22.9 \mathrm{kcal} / \mathrm{mol}$

Scheme 5: Rotational barriers of substrates and intermediates calculated at the B3YLP/6-31G(d) level of theory.

temperature. Furthermore, it is also important to employ substrates bearing bulky substituents on the nitrogen atom. Such substrates limit the bond rotation about the chiral axis to realize high enantioselectivity (Scheme 1). The rotational barriers of monobrominated compounds $\mathbf{1 p}$ and $\mathbf{1 q}$ (bearing methyl and isobutyl groups, respectively, on the amide moiety) are lower than that of $\mathbf{1 m}$. Although racemization of $\mathbf{2 b}$, the rotational barrier of which is $22.9 \mathrm{kcal} / \mathrm{mol}$, was observed after a lot of months, it is enough slow to enable the immediate analysis of the reaction selectivity (the decrease of the enantiomeric purity of $\mathbf{2} \mathbf{b}$ was negligible after a day). 
Furthermore, the reaction of benzamide $\mathbf{5}$, bearing a protected phenol, was carried out (Scheme 6). It failed to give the corresponding product 6 , indicating the significance of multipoint activation involving the phenolic hydroxy group.

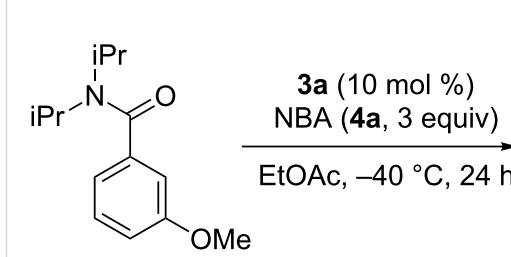

5<smiles>COc1c(Br)cc(Br)c(C(=O)N(C(C)C)C(C)C)c1Br</smiles>

6

N.D.

(recovery of $\mathbf{5}$ : $>99 \%$ )
Scheme 6: Reaction of substrate with protected phenol.

\section{Conclusion}

In summary, we demonstrated a novel enantioselective synthesis of axially chiral benzamides, using bifunctional organocatalysts, via aromatic electrophilic halogenation. Moderate to good enantioselectiveties were accomplished with various benzamide substrates. These results, along with ones reported in our previous work and other literature [35-38,58,59], verify the utility of bifunctional organocatalysts for application in the synthesis of various axially chiral compounds. Further studies regarding the detailed clarification of the reaction mechanism and application of this method to the construction of other axially chiral structures are currently underway and will be reported in due course.

\section{Supporting Information}

\section{Supporting Information File 1}

Experimental procedures, characterization data, copies of the ${ }^{1} \mathrm{H},{ }^{13} \mathrm{C}$ NMR spectra, HPLC chromatogram profiles, and the ORTEP drawing.

[http://www.beilstein-journals.org/bjoc/content/ supplementary/1860-5397-13-151-S1.pdf]

\section{Supporting Information File 2}

Crystallographic information file of compound $\mathbf{2 d}$.

[http://www.beilstein-journals.org/bjoc/content/ supplementary/1860-5397-13-151-S2.cif]

\section{Acknowledgements}

We thank Professor Takuya Kurahashi (Kyoto University) for X-ray crystallographic analysis. This work was supported financially by the Japanese Ministry of Education, Culture, Sports,
Science and Technology (15H05845 and 16K13994). K.A. also acknowledges the Asahi Glass Foundation, Toyota Physical and Chemical Research Institute, Tokyo Institute of Technology Foundation, the Naito Foundation, Research Institute for Production Development, the Tokyo Biochemical Research Foundation, the Uehara Memorial Foundation, and the Kyoto University Foundation. R.M. and A.M. also acknowledge the Japan Society for the Promotion of Science for Young Scientists for the fellowship support.

\section{References}

1. Okino, T.; Hoashi, Y.; Takemoto, Y. J. Am. Chem. Soc. 2003, 125, 12672. doi:10.1021/ja036972z

2. Okino, T.; Hoashi, Y.; Furukawa, T.; Xu, X.; Takemoto, Y. J. Am. Chem. Soc. 2005, 127, 119. doi:10.1021/ja044370p

3. Vakulya, B.; Varga, S.; Csámpai, A.; Soós, T. Org. Lett. 2005, 7, 1967. doi:10.1021/ol050431s

4. Hamza, A.; Schubert, G.; Soós, T.; Pápai, I. J. Am. Chem. Soc. 2006, 128, 13151. doi:10.1021/ja063201x

5. Connon, S. J. Chem. - Eur. J. 2006, 12, 5418. doi:10.1002/chem.200501076

6. Zhu, J.-L.; Zhang, Y.; Liu, C.; Zheng, A.-M.; Wang, W. J. Org. Chem. 2012, 77, 9813. doi:10.1021/jo302133n

7. Asano, K.; Matsubara, S. J. Am. Chem. Soc. 2011, 133, 16711. doi:10.1021/ja207322d

8. Asano, K.; Matsubara, S. Org. Lett. 2012, 14, 1620. doi:10.1021/ol3003755

9. Okamura, T.; Asano, K.; Matsubara, S. Chem. Commun. 2012, 48, 5076. doi:10.1039/c2cc31602a

10. Fukata, Y.; Asano, K.; Matsubara, S. Chem. Lett. 2013, 42, 355. doi:10.1246/cl.121245

11. Fukata, Y.; Miyaji, R.; Okamura, T.; Asano, K.; Matsubara, S. Synthesis 2013, 45, 1627. doi:10.1055/s-0032-1316920

12. Miyaji, R.; Asano, K.; Matsubara, S. Org. Lett. 2013, 15, 3658. doi:10.1021/ol401538b

13. Fukata, Y.; Asano, K.; Matsubara, S. J. Am. Chem. Soc. 2013, 135, 12160. doi:10.1021/ja407027e

14. Miyaji, R.; Asano, K.; Matsubara, S. Org. Biomol. Chem. 2014, 12, 119. doi:10.1039/c3ob41938j

15. Yoneda, N.; Hotta, A.; Asano, K.; Matsubara, S. Org. Lett. 2014, 16, 6264. doi:10.1021/ol503104b

16. Yoneda, N.; Fukata, Y.; Asano, K.; Matsubara, S. Angew. Chem., Int. Ed. 2015, 54, 15497. doi:10.1002/anie.201508405

17. Brandes, S.; Bella, M.; Kjærsgaard, A.; Jørgensen, K. A. Angew. Chem., Int. Ed. 2006, 45, 1147. doi:10.1002/anie.200503042

18. Brandes, S.; Niess, B.; Bella, M.; Prieto, A.; Overgaard, J.; Jørgensen, K. A. Chem. - Eur. J. 2006, 12, 6039. doi:10.1002/chem.200600495

19. Li, G.-Q.; Gao, H.; Keene, C.; Devonas, M.; Ess, D. H.; Kürti, L. J. Am. Chem. Soc. 2013, 135, 7414. doi:10.1021/ja401709k

20. Wang, J.-Z.; Zhou, J.; Xu, C.; Sun, H.; Kürti, L.; Xu, Q.-L. J. Am. Chem. Soc. 2016, 138, 5202. doi:10.1021/jacs.6b01458

21. De, C. K.; Pesciaioli, F.; List, B. Angew. Chem., Int. Ed. 2013, 52, 9293. doi:10.1002/anie.201304039

22. Chen, Y.-H.; Cheng, D.-J.; Zhang, J.; Wang, Y.; Liu, X.-Y.; Tan, B. J. Am. Chem. Soc. 2015, 137, 15062. doi:10.1021/jacs.5b10152 
23. Moliterno, M.; Cari, R.; Puglisi, A.; Antenucci, A.; Sperandio, C.; Moretti, E.; Di Sabato, A.; Salvio, R.; Bella, M. Angew. Chem., Int. Ed. 2016, 55, 6525. doi:10.1002/anie.201601660

24. Zhang, H.-H.; Wang, C.-S.; Li, C.; Mei, G.-J.; Li, Y.; Shi, F. Angew. Chem., Int. Ed. 2017, 56, 116. doi:10.1002/anie.201608150

25. Chan, V.; Kim, J. G.; Jimeno, C.; Carroll, P. J.; Walsh, P. J. Org. Lett. 2004, 6, 2051. doi:10.1021/ol0492952

26. Gustafson, J. L.; Lim, D.; Miller, S. J. Science 2010, 328, 1251. doi:10.1126/science.1188403

27. Pathak, T. P.; Miller, S. J. J. Am. Chem. Soc. 2012, 134, 6120. doi:10.1021/ja301566t

28. Barrett, K. T.; Miller, S. J. J. Am. Chem. Soc. 2013, 135, 2963. doi:10.1021/ja400082x

29. Barrett, K. T.; Metrano, A. J.; Rablen, P. R.; Miller, S. J. Nature 2014, 509, 71. doi:10.1038/nature13189

30. Diener, M. E.; Metrano, A. J.; Kusano, S.; Miller, S. J. J. Am. Chem. Soc. 2015, 137, 12369. doi:10.1021/jacs.5b07726

31. Cozzi, P. G.; Emer, E.; Gualandi, A. Angew. Chem., Int. Ed. 2011, 50, 3847. doi:10.1002/anie.201008031

32. Shirakawa, S.; Liu, K.; Maruoka, K. J. Am. Chem. Soc. 2012, 134, 916. doi:10.1021/ja211069f

33. Liu, K.; Wu, X.; Kan, S. B. J.; Shirakawa, S.; Maruoka, K. Chem. - Asian J. 2013, 8, 3214. doi:10.1002/asia.201301036

34. Nushiro, K.; Kikuchi, S.; Yamada, T. Chem. Lett. 2013, 42, 165. doi:10.1246/cl.2013.165

35. Zhao, P.; Beaudry, C. M. Angew. Chem., Int. Ed. 2014, 53, 10500. doi:10.1002/anie.201406621

36. Miyaji, R.; Asano, K.; Matsubara, S. J. Am. Chem. Soc. 2015, 137, 6766. doi:10.1021/jacs.5b04151

37. Miyaji, R.; Asano, K.; Matsubara, S. Chem. - Eur. J. 2017, 23, 9996. doi:10.1002/chem.201701707

38. Yu, C.; Huang, H.; Li, X.; Zhang, Y.; Wang, W. J. Am. Chem. Soc. 2016, 138, 6956. doi:10.1021/jacs.6b03609

39. Mori, K.; Itakura, T.; Akiyama, T. Angew. Chem., Int. Ed. 2016, 55, 11642. doi:10.1002/anie.201606063

40. Staniland, S.; Adams, R. W.; McDouall, J. J. W.; Maffucci, I.; Contini, A.; Grainger, D. M.; Turner, N. J.; Clayden, J. Angew. Chem., Int. Ed. 2016, 55, 10755. doi:10.1002/anie.201605486

41. Jolliffe, J. D.; Armstrong, R. J.; Smith, M. D. Nat. Chem. 2017, 9, 558. doi:10.1038/nchem.2710

42. Shirakawa, S.; Wu, X.; Maruoka, K. Angew. Chem., Int. Ed. 2013, 52, 14200. doi:10.1002/anie.201308237

43. Shirakawa, S.; Wu, X.; Liu, S.; Maruoka, K. Tetrahedron 2016, 72, 5163. doi:10.1016/j.tet.2015.10.074

44. Cheng, D.-J.; Yan, L.; Tian, S.-K.; Wu, M.-Y.; Wang, L.-X.; Fan, Z.-L.; Zheng, S.-C.; Liu, X.-Y.; Tan, B. Angew. Chem., Int. Ed. 2014, 53, 3684. doi:10.1002/anie.201310562

45. Lu, S.; Poh, S. B.; Zhao, Y. Angew. Chem., Int. Ed. 2014, 53, 11041. doi:10.1002/anie.201406192

46. Ma, G.; Deng, J.; Sibi, M. P. Angew. Chem., Int. Ed. 2014, 53, 11818. doi:10.1002/anie.201406684

47. Wang, J.; Chen, M.-W.; Ji, Y.; Hu, S.-B.; Zhou, Y.-G. J. Am. Chem. Soc. 2016, 138, 10413. doi:10.1021/jacs.6b06009

48. Matsumoto, T.; Konegawa, T.; Nakamura, T.; Suzuki, K. Synlett 2002, 122. doi:10.1055/s-2002-19349

49. Okuyama, K.; Shingubara, K.; Tsujiyama, S.; Suzuki, K.; Matsumoto, T. Synlett 2009, 941. doi:10.1055/s-0028-1088215

50. Mori, K.; Ichikawa, Y.; Kobayashi, M.; Shibata, Y.; Yamanaka, M.; Akiyama, T. J. Am. Chem. Soc. 2013, 135, 3964. doi:10.1021/ja311902f
51. Mori, K.; Ichikawa, Y.; Kobayashi, M.; Shibata, Y.; Yamanaka, M.; Akiyama, T. Chem. Sci. 2013, 4, 4235. doi:10.1039/c3sc52142g

52. Mori, K.; Kobayashi, M.; Itakura, T.; Akiyama, T. Adv. Synth. Catal. 2015, 357, 35. doi:10.1002/adsc.201400611

53. Armstrong, R. J.; Smith, M. D. Angew. Chem., Int. Ed. 2014, 53, 12822. doi:10.1002/anie.201408205

54. Zhang, J.-W.; Xu, J.-H.; Cheng, D.-J.; Shi, C.; Liu, X.-Y.; Tan, B. Nat. Commun. 2016, 7, No. 10677. doi:10.1038/ncomms10677

55. Link, A.; Sparr, C. Angew. Chem., Int. Ed. 2014, 53, 5458. doi:10.1002/anie.201402441

56. Lotter, D.; Neuburger, M.; Rickhaus, M.; Häussinger, D.; Sparr, C. Angew. Chem., Int. Ed. 2016, 55, 2920. doi:10.1002/anie.201510259

57. Fäseke, V. C.; Sparr, C. Angew. Chem., Int. Ed. 2016, 55, 7261. doi:10.1002/anie.201602689

58. Quinonero, O.; Jean, M.; Vanthuyne, N.; Roussel, C.; Bonne, D.; Constantieux, T.; Bressy, C.; Bugaut, X.; Rodriguez, J. Angew. Chem., Int. Ed. 2016, 55, 1401. doi:10.1002/anie.201509967

59. Raut, V. S.; Jean, M.; Vanthuyne, N.; Roussel, C.; Constantieux, T.; Bressy, C.; Bugaut, X.; Bonne, D.; Rodriguez, J. J. Am. Chem. Soc. 2017, 139, 2140. doi:10.1021/jacs.6b11079

60. Li, S.; Zhang, J.-W.; Li, X.-L.; Cheng, D.-J.; Tan, B. J. Am. Chem. Soc. 2016, 138, 16561. doi:10.1021/jacs.6b11435

61. Zhang, L.; Zhang, J.; Ma, J.; Cheng, D.-J.; Tan, B. J. Am. Chem. Soc. 2017, 139, 1714. doi:10.1021/jacs.6b09634

62. Shirakawa, S.; Liu, S.; Kaneko, S. Chem. - Asian J. 2016, 11, 330. doi:10.1002/asia.201500951

63. Wencel-Delord, J.; Panossian, A.; Leroux, F. R.; Colobert, F. Chem. Soc. Rev. 2015, 44, 3418. doi:10.1039/c5cs00012b

64. Barrett, K. T.; Miller, S. J. Org. Lett. 2015, 17, 580. doi:10.1021/ol503593y

65. Clayden, J.; Pink, J. H. Angew. Chem., Int. Ed. 1998, 37, 1937. doi:10.1002/(SICI)1521-3773(19980803)37:13/14<1937::AID-ANIE193 $7>3.0 . \mathrm{CO} ; 2-4$

\section{License and Terms}

This is an Open Access article under the terms of the Creative Commons Attribution License (http://creativecommons.org/licenses/by/4.0), which permits unrestricted use, distribution, and reproduction in any medium, provided the original work is properly cited.

The license is subject to the Beilstein Journal of Organic Chemistry terms and conditions:

(http://www.beilstein-journals.org/bjoc)

The definitive version of this article is the electronic one which can be found at: doi:10.3762/bjoc.13.151 